\title{
Boléro unravelled: a case of musical perseveration
}

\author{
Eva M. Cybulska
}

Maurice Ravel (1875-1937), a musician of the highest order, died in a state of dementia. A genius of orchestration, a successful experimenter in musical forms and styles; he was at his best when given to composing small-scale constructions. His musical miniatures combine an extraordinary expressiveness with an unparalleled, almost mechanical precision. The latter quality provoked Stravinsky into calling him a "Swiss clock-maker of music".

The eldest child of a Swiss engineer and a Basque woman, he was brought up and spent most of his life in Paris. Ravel always felt an intense need for privacy. His sexual life was shrouded in secrecy, as was his musical creativity. He tended to expose his music only when the final touch had been applied to its composition. His need for a near absolute certainty in the realm of music making only matched his vulnerability, his insecurity as a person. While for Debussy music was an evolution, for Ravel it was a crystallisation. He worked in solitude and with intense concentration. The end result was like his dress; impeccably elegant and restrained, undeniably French. Ravel's adoption of the dress and manners of the fin de siecle dandy possibly served to compensate for his small stature. Always meticulous about his personal appearance, he was unlikely to present himself, as he would a composition, to the world in an 'unfinished' state. His relationships with people were, to some extent, substituted by a fantastic world of fairytales and magic as in Shéhérezade, Daphnis et Chloé, Rêves and Gaspard de la Nuit. Throughout his life he collected mechanical toys and various bibelots. His musical output was not prolific and periods of creative activity were interspersed with intervals of compositional silence. For the last five years of his life he composed almost nothing.

\section{The Iliness}

The earliest signs of neurological problems appeared in 1927 when Ravel (age 52) became disorientated during a performance of his music at a concert. He also made numerous blunders while writing music. Nevertheless, he still com- pleted a successful tour of the US in 1928, and appeared to have achieved an almost complete recovery. In the autumn of 1932 his lllness took a turn for the worse after an automobile accident. Many of those close to him noticed his increasing lassitude and apathy. His coordination deteriorated and in November 1933 he could scarcely conduct his G-minor Piano Concerto so that the orchestra virtually proceeded on its own. Ravel's decision to consult the famous neurologist Théophile Alajouanine was prompted by his friends who became alarmed by the composer's increasing difficulties in communicating his musical ideas. The most striking features of Ravel's illness were aphasia, agraphia, alexia, amusia and ideo-motor apraxia. His memory, judgement, affect and the sense of aesthetics were relatively preserved, though the verbal expression of these was impeded. Alajouanine (1948) expressed succinctly the essence of this tragedy "to conceive is nothing - to express is all". Ravel died following a poorly planned neurosurgical procedure, which aimed at excluding a cerebral tumour. There was no postmortem. Henson (1988) suggests that death was due to a subdural haematoma and that the likely cause of Ravel's illness was a restricted form of cerebral degeneration. He refers to the results of necropsy on two patients with progressive aphasia, which showed spongiform cortical degeneration involving the left inferior frontal gyrus. However, a multi-infarct state or even Alzheimer's disease cannot be excluded.

\section{Boléro}

This was one of Ravel's last compositions. It was originally conceived in 1928 as a ballet piece for Ida Rubinstein. Almost to the composer's annoyance it became an instant hit. "This is not music but a piece for orchestra" he was quoted to have said (Goss, 1945). The most striking feature of Bolero is the throbbing rhythm of obsessive almost hallucinatory insistence, a sort of 'Danse Macabre'. The simple rhythmical pattern consisting of two bars virually imprisons the whole composition. A single melody (no doubt reminiscent of Ravel's Basque origins), expressed in 16 
bars is repeated, without evolution, 18 times in 17 minutes. Following a four-bar introduction by the percussion and cellos, during which the rhythm is established, the flute introduces the melody. As other instruments then repeat the melody, the texture slowly begins to thicken as woodwind, harp, strings and finally brass are added. The piece begins pianissimo and progresses steadily to fortissimo, with the crescendo being achieved by enlargement of orchestration and volume. The melody's sudden collapse is reminiscent of a sexual orgasm or death, leaving the listener to cope with his own throbbing pain, fear and excitement.

Every creative work reflects the personality of its author. Could it be that Boléro represents a form of musical perseveration? Ravel composed it shortly after the emergence of the first neurological signs and symptoms. According to Neary (1988) perseveration is one of the most striking features in patients with fronto-temporal atrophy. Boléro is more than a musical tour de force, it contains an unexpected tragic element at its close. "It is a confession of the nightmare which haunted Ravel and of the dark anguish which tormented his soul" (Svarèz, 1938). One day a friend who found Ravel motionless, silent and absorbed, asked "What are you doing?" He replied "J'attends ... Je m'en vais par morceaux" (Goss, 1945). Perhaps even the composer's illness had a 'caractère ravélienne', and resembled a clock that was slowly going to pieces, watching its own destruction.

\section{Acknowledgement}

I thank Kaj Rucinski for his help with the musical analysis of Boléro.

\section{Reference}

Alajouanine, Th. (1948) Aphasia and artistic realisation. Brain, 71, 229-241.

Goss, M. (1945) Boléro: The Life of Maurice Ravel. New York: Tudor Publishing.

HENSON, R. A. (1988) Maurice Ravel's illness: a tragedy of lost creativity. British Medical Journal, 286, 1585-1588.

NEARY, D., SNOWDEN, J. S., NORTHERN, B., et al (1988) Dementia of frontal lobe type. Journal of Neurology. Neurosurgery and Psychiatry. 61, 353-361.

Svarez, A. (1938) "Esquisse" in Revue Musicale, December issue.

Eva M. Cybulska, Stone House Hospital, Thameslink Healthcare Services, Dartford, Kent DA2 6AU 